\title{
Stimulative Effect of Jasmonic Acid on Callus Formation in Apple Fruit
}

\author{
Satoru Kondo * , Naoko Tsukada and Yoshiyuki Niimi \\ School of Bioresources, Hiroshima Prefectural University, Shobara, Hiroshima 727-0023
}

\begin{abstract}
Summary
The role of jasmonic acid (JA) in callus formation was investigated on discs taken from the pulp of apple (Malus pumila Mill. var. domestica Schneid.), sampled on 15, 25, and 35 days after full bloom (DAFB), and cultured on B5 medium, containing combinations of naphthalene acetic acid (NAA), benzyladenine (BA), and JA. On the 15 DAFB sample, $0.45 \mu \mathrm{M}, 1.0 \mu \mathrm{M}$, and $4.5 \mu \mathrm{M}$ JA in the presence of $10.7 \mu \mathrm{M}$ NAA induced greater callus formation than did the sample without JA. However, this effect of JA at 15 DAFB was not observed except when it was combined with only NAA; $4.5 \mu \mathrm{M}$ JA inhibited the callus formation. The presence of JA inhibited callus formation on discs taken 25 and 35 DAFB. Endogenous JA concentration of apple pulp at 15 DAFB was lower than that at 25 and 35 DAFB. These results indicate that the low endogenous JA concentration early in fruit development promotes callus formation; whereas, increasing JA concentration inhibits it.
\end{abstract}

Key Words: callus formation, jasmonic acid, Malus pumila var. domestica.

\section{Introduction}

The physiological roles of jasmonates have been investigated in many plants. In most cases, jasmonates are inhibitory to plant growth, e.g. jasmonic acid (JA) and methyl jasmonate (MeJA) inhibited cell division and enlargement in soybean (Glycine max Merrill) and radish (Raphanus sativus L.) (Ueda and Kato, 1982). We found that in apple (Malus pumila var. domestica) the concentrations of JA were high in the early growth stages of pulp development (Kondo et al., 2000), indicating that jasmonates may influence cell division or cell enlargement. However, there are no reports on the effect of JA on cell division and enlargement at the beginning of apple fruit development. The objective of this study is to ascertain the action of jasmonates in callus formation of young apple fruit.

\section{Materials and Methods}

'Tsugaru' apple fruit were obtained from fifteen randomly selected 11-year-old trees grafted onto Malling 26 (M. 26) rootstocks, growing in an open field at Hiroshima Prefectural University in 1999.

Samples were collected 15,25 , and 35 days after full bloom (DAFB). Discs, $4 \mathrm{~mm}$ in diameter and $3 \mathrm{~mm}$ in thickness were excised with a cork borer from apple pulp. The average weight of 30 discs was $14.5 \pm 0.43$ (SE) $\mathrm{mg}$. To determine the effects on the induction of callus weight gain, 16 groups of six discs were placed on $40 \mathrm{~m} l \mathrm{~B} 5$ medium (Nomura and Masuda, 1998), containing $0.08 \mathrm{M}$ sucrose. In addition, $0.89 \mu \mathrm{M}$ BA with

Received; July 17, 2000. Accepted; August 30, 2000.

*Corresponding author : e-mail: s-kondo@bio.hiroshima-pu.ac.jp
$10.7 \mu \mathrm{M}$ NAA, $0.89 \mu \mathrm{M}$ BA alone, or $10.7 \mu \mathrm{M}$ NAA alone were included on 4 media; the last 4 groups were hormone-free. These discs were cultured in petri dishes with different concentrations of JA $(0,0.45,1.0$ and 4.5 $\mu \mathrm{M})$ in a $4 \times 4$ factorial design. This entire treatment was replicated 5 times ( 80 total cultures). The medium was adjusted to $\mathrm{pH} 5.8$ with $1 \mathrm{M} \mathrm{KOH}$ before adding $0.3 \%(\mathrm{w} / \mathrm{v})$ gellan gum, and autoclaved at $1.2 \mathrm{~kg} \cdot \mathrm{cm}^{-2}$ for $20 \mathrm{~min}$. JA in methanol was added after the temperature fell to $45^{\circ} \mathrm{C}$. Three randomly selected discs per apple were placed in one petri dish; the plates were sealed with parafilm and incubated for 30 days at $25^{\circ} \mathrm{C}$ in the dark.

JA concentration in apple pulp was measured, according to Kondo et al. (2000). Fruit samples (15 g fresh weight; five replications of 50 fruit) were homogenized in $20 \mathrm{~m} l$ saturated $\mathrm{NaCl}$ solution, $1 \mathrm{ml} 1 \mathrm{~mol}$ citric acid, and $50 \mathrm{~m} l$ diethyl ether that contained $11.3 \mu \mathrm{mol}$ butylated hydroxytoluene as an antioxidant with $1 \mu \mathrm{g}$ $( \pm)-2-\left(2,3-{ }^{2} \mathrm{H}_{2}\right) \mathrm{JA}$ as the internal standard. After JA in the sample was derivatized by pentafluorobenzyl (PFB) bromide, the level of the derivatives was determined by gas chromatography - mass spectrometry (GCMS) [QP 5000; Shimadzu Scientific Instruments, Inc., Kyoto; column $=\mathrm{CP}-\mathrm{Sil}$ 5CB(Chrompack, Inc., Middelburg, Netherlands; $0.25 \mathrm{~mm} \times 25 \mathrm{~m}$ ); linear He flow at $50.2 \mathrm{~cm} \cdot \mathrm{sec}^{-1}$, column temperature had a step gradient of $60^{\circ} \mathrm{C}$ for $2 \mathrm{~min}, 60$ to $270^{\circ} \mathrm{C}$ at $10^{\circ} \mathrm{C} \cdot \mathrm{min}^{-1}$, and $270^{\circ} \mathrm{C}$ for $35 \mathrm{~min}$; electron potential, $70 \mathrm{eV}$ ]. The analyses were performed using selected ion monitoring mode. Retention times of JA derivatives were trans-JA, $19.47 \mathrm{~min} ;{ }^{2} \mathrm{H}_{2}$ - JA, $19.47 \mathrm{~min}$, and cis-JA, $19.75 \mathrm{~min}$. Ions of $\mathrm{m} / \mathrm{z} 392,390,211$, and 209 were monitored for trans-JA, cis-JA and ${ }^{2} \mathrm{H}_{2}$-JA. JA concentration was 
measured from the ratio of peak areas for $m / z 209\left({ }^{2} \mathrm{H}_{0}\right)$ $1211\left({ }^{2} \mathrm{H}_{2}\right)$. The total of trans-JA and cis-JA is expressed as JA.

Standard errors and significant differences between treatments were performed using the Newmen-Keuls test (SPSS Inc., Chicago, Ill.)

\section{Results and Discussion}

The combination of BA plus NAA promoted greater increases in callus weight than did media with only BA, NAA or that free of hormones (Fig.1). JA at $4.5 \mu \mathrm{M}$ was the least effective at promoting callus growth in a medium containing BA and NAA. Jasmonates had little or no effect on callus weight gain in discs incubated without hormonal additives or with BA, whereas some gained weight when JA was added to NAA-incubated

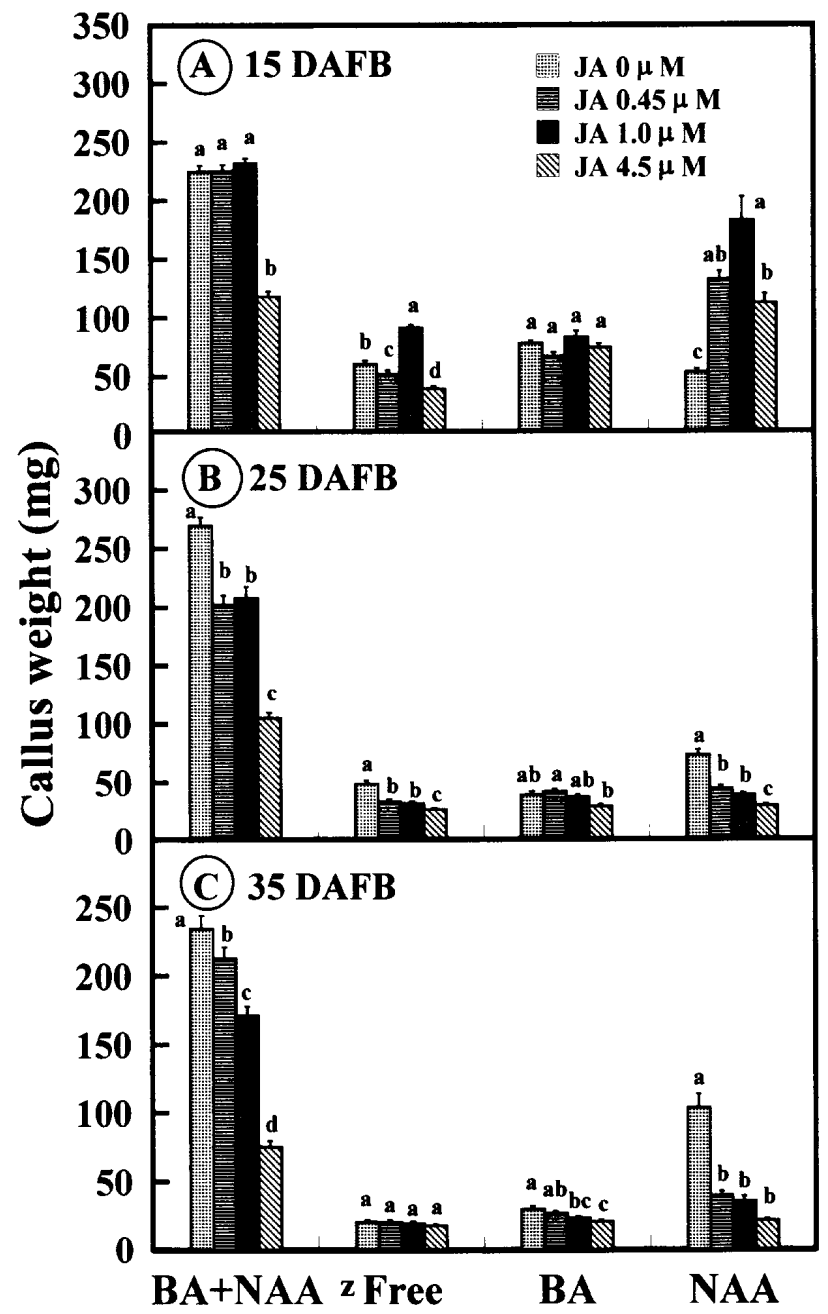

Fig. 1. Effect of JA concentration on callus weight gain of 'Tsugaru' apple discs from (A) 15 , (B) 25 , and (C) 35 DAFB. The discs on $\mathrm{B} 5$ medium with or without $0.89 \mu \mathrm{M}$ BA plus $10.7 \mu \mathrm{M}$ NAA, $0.89 \mu \mathrm{M}$ BA, or $10.7 \mu \mathrm{M}$ NAA were incubated with $0,0.45,1$, and $4.5 \mu \mathrm{M} \mathrm{JA}$ for 30 days at $25^{\circ} \mathrm{C}$ in the dark. Data represent means $\pm \mathrm{SE}$ of five replications. Data points within each treatment (BA+NAA, hormone - free ${ }^{z}, \mathrm{BA}$, and NAA) with different letters show significant differences as calculated by Newmen - Keuls test, $P \leqq 0.05$.
Table 1. JA concentrations ( $\mathrm{nmol} \cdot \mathrm{kg} \mathrm{FW}^{-1}$ ) in the pulp of apples.

\begin{tabular}{cc}
\hline \hline Days after full bloom & JA concentration \\
\hline 15 & $92.1 \pm 7.9$ \\
25 & $132.5 \pm 8.3$ \\
35 & $213.2 \pm 17.1$ \\
\hline
\end{tabular}

Data are means \pm SE of five replications.

callus. JA at $0.45 \mu \mathrm{M}, 1.0 \mu \mathrm{M}$ and $4.5 \mu \mathrm{M}$ at 15 DAFB promoted significantly more callus formation, compared to the sample without JA; but JA inhibited callus induction even when it combined with NAA at 25 and 35 DAFB.

Auxin induces cell expansion in plants, and cytokinin, which plays a role in cell division, becomes more active in the presence of auxin (Masuda et al., 1971). The promotive effect of JA in the presence of NAA 15 DAFB indicates that JA may stimulate cell division as cytokinin does. Although most studies have reported inhibitory action of JA on cell division and enlargement (Ravnikar and Gogala, 1990; Ravnikar et al., 1990; Ueda and Kato, 1982), others have shown that JA in lower concentrations stimulate them (Ravnikar et al., 1992; Yoshihara et al., 1989). There are some possible explanations for the difference on the effect of JA on the callus formation in apple pulp between 15 DAFB and 25 and 35 DAFB. One is that endogenous JA concentration in apple pulp more than doubled between 15 and 35 DAFB (Table 1). In the BA plus NAA treatment where callus formation increased greatly when compared to the other treatments, $4.5 \mu \mathrm{M} \mathrm{JA}$ inhibited callus formation only at 15 DAFB. However, at 25 and 35 DAFB all JA concentrations from $0.45 \mu \mathrm{M} \mathrm{JA}$ to $4.5 \mu \mathrm{M}$ JA inhibited callus formation; the degree of growth inhibition increased with time. Therefore, JA at any concentration applied exogenously might inhibit callus formation at a later stage of fruit development because endogenous JA concentrations increase with time.

Another factor is that the cells of apple fruit generally divide for 30 days after fertilization and then gradually begins to enlarge (Ryugo, 1988). Therefore, in experiment, ovarian tissue 15 DAFB was still in the cell division stage. Hence, the promotion of callus formation by JA at 15 DAFB demonstrates that low JA concentrations may promote the cell division but inhibit cell enlargement. The threshold for response to JA may differ for each fruit growth stage and by interactions with other endogenous hormones.

\section{Literature Cited}

Kondo, S., A. Tomiyama and H. Seto. 2000. Changes of endogenous jasmonic acid and methyl jasmonate in apples and sweet cherries during fruit development. J. Amer. Soc. Hort. Sci. 125: 282- 287.

Masuda, Y., M. Katsumi and H. Imaseki. 1971. Plant 
hormone. p. 193-250. Asakura Press, Tokyo.

Nomura, K. and K. Masuda. 1998. Medium. p. 17-39. In: A. Komamine and K. Nomura (eds.). Experimental method of biological chemistry 41: Introduction of plant cell technology. Japan Scientific Societies Press, Tokyo.

Ravnikar, M. and N. Gogala. 1990. Regulation of potato meristem development by jasmonic acid in vitro. $\mathrm{J}$. Plant Growth Regulat. 9: 233-236.

Ravnikar, M., J. Rode, N. Gogala and D. Benedicic. 1990. Regulation of organogenesis with jasmonic acid. Acta Hort. 280: 169-172.

Ravnikar, M., B. Vilhar and N. Gogala. 1992. Stimulatory effects of jasmonic acid on potato stem node and protoplast culture. J. Plant Growth Regulat. 11: 29-33.

Ryugo, K. 1988. Fruit growth and development. p.107-168. In: K. Ryugo (ed.). Fruit culture-- Its science and art. Wiley, New York.

Ueda, J. and J. Kato. 1982. Inhibition of cytokinin-induced plant growth by jasmonic acid and its methyl ester. Physiol. Plant. 54: 249-252.

Yoshihara, T., E. S. A. Omer, H. Koshino, S. Sakamura, Y. Kikuta and Y. Koda. 1989. Structure of a tuber-inducing stimulus from potato leaves (Solanum tuberosum L.). Agr. Bol. Chem. 53: 2835-2837.
リンゴ果実のカルス形成に及ぼすジャスモン酸 の促進効果

近藤 悟 - 塚田直子・新美善行

広島県立大学生物資源学部 727-0023 庄原市七塚町 562

\section{摘 要}

満開後 15 日，25日および 35 日のリンゴ果肉ディスクから のカルス形成に及ぼすジャスモン酸 (JA)の影響を検討した. 果肉ディスクをナフタレン酢酸 (NAA), ベンジルアデニン (BA) およびJA を組み合わせた試験液を含む B5 培地に置床 した，満開後 15 日の果肉ディスクのカルス形成は，NAA と $0.45 \mu \mathrm{M}, 1.0 \mu \mathrm{M}$ および $4.5 \mu \mathrm{M}$ 各々の JA濃度の組合せで促 進された。一方 NAAのみ上の組合せ以外ではJAの促進効果 は観察されず， $4.5 \mu \mathrm{M} \mathrm{JA}$ はカルス形成を抑制した. 満開後 25 日および 35 日の果肉ディスクのカルス形成は, JAの存在 によって抑制された。内生JA濃度は満開後 25 日および 35 日 に比べ，満開後 15 日で低かった．以上より，果実発育のごく 初期には内生 JA濃度が低く，その時期に限りJAのカルス形 成促進効果が認められること, また高濃度の JAは逆に阻害す ることが示唆された。 